\title{
MARCO PICCAT, La vera storia di 'Jehanne de Naplez et de Cecile...', contessa di Provenza e principessa d'Acaja, secondo Tommaso III, marchese di Saluzzo
}

\section{Maria Colombo Timelli}

\section{(2) OpenEdition}

1 Journals

\section{Édition électronique}

URL : https://journals.openedition.org/studifrancesi/44724

DOI : $10.4000 /$ studifrancesi. 44724

ISSN : 2421-5856

Éditeur

Rosenberg \& Sellier

\section{Édition imprimée}

Date de publication : 1 août 2021

Pagination : 351

ISSN : 0039-2944

\section{Référence électronique}

Maria Colombo Timelli, « mARco PICcat, La vera storia di 'Jehanne de Naplez et de Cecile..., contessa di

Provenza e principessa d'Acaja, secondo Tommaso III, marchese di Saluzzo », Studi Francesi [En ligne], 194 (LXV | II) | 2021, mis en ligne le 06 septembre 2021, consulté le 15 octobre 2022. URL : http://

journals.openedition.org/studifrancesi/44724; DOI : https://doi.org/10.4000/studifrancesi.44724

Ce document a été généré automatiquement le 15 octobre 2022.

\section{(c) $(1) \odot$}

Creative Commons - Attribution - Pas d'Utilisation Commerciale - Pas de Modification 4.0 International - CC BY-NC-ND 4.0

https://creativecommons.org/licenses/by-nc-nd/4.0/ 


\title{
MARCO PICCAT, La vera storia di 'Jehanne de Naplez et de Cecile...', contessa di Provenza e principessa d'Acaja, secondo Tommaso III, marchese di Saluzzo
}

\author{
Maria Colombo Timelli
}

\section{RÉFÉRENCE}

MARCO PICCAT, La vera storia di 'Jehanne de Naplez et de Cecile...', contessa di Provenza e principessa d'Acaja, secondo Tommaso III, marchese di Saluzzo, in Studi sulla Letteratura Cavalleresca in Francia e in Italia (secoli XIII-XVI), Volume III, a cura di M. Lecco, Alessandria, Edizioni dell'Orso, 2020, pp. 97-110.

1 Accusée d'avoir assassiné son mari, la reine Jeanne de Naples a joui, de son vivant déjà, d'une renommée noire. Après avoir rappelé les témoignages célèbres de Pétrarque et de Boccace d'abord, puis de sainte Brigide de Suède et de sainte Catherine de Sienne, qui fréquentèrent tous et toutes la cour et connurent personnellement Jeanne, M.P. montre comment, dans le Chevalier errant, Thomas de Saluce affirme résolument son appartenance au monde culturel et politique français, en blanchissant la reine et en lui attribuant les qualités d'une régnante, elle «qui si doulcement gouverna son royaume» (cit. p. 98). 